\title{
Wkład jezuitów w upowszechnienie katechizmów w Rzeczypospolitej w XVI wieku
}

\begin{abstract}
radycja katechizmów sięga pierwszych wieków chrześcijaństwa, na przestrzeni dziejów spełniały one rolę kompendiów wiedzy o zasadach religijnych poszczególnych wspólnot. Wielkie odrodzenie przeżywały w XVI w., kiedy istniała szansa wzajemnego pojednania wspólnot chrześcijańskich, stały się świadectwem znaczenia, jakim darzono Słowo Boże w tych czasach. Katechizmy katolickie pozwalają dostrzec zainteresowanie Kościoła katolickiego Biblią oraz tradycja pierwszych wieków chrześcijaństwa.
\end{abstract}

\section{AUTORZY - JEZUICI}

Swój udział w przygotowywaniu katechizmów w XVI w. mieli członkowie Towarzystwa Jezusowego. Byli oni prekursorami wykorzystania katechizmow w pracy duszpasterskiej ${ }^{1}$ w niespotykanej dotąd skali, skierowanej na podjęcie pozytywnej walki z różnowiercami. Nic więc dziwnego, że potrzebując takiego rodzaju orędzia w krzewieniu wiary, sami podejmowali się ich pisania i tłumaczenia. Na obszarze Rzeczypospolitej ukazały się prace: Benedykta Herbesta - autora pierwszego polskiego katechizmu, Roberta Bellarmina - który za zasługi w szerzeniu wiary został kardynałem, a także Piotra Kanizjusza - kaznodziei zwalczającego teologiczną niejasność $i$ ignorancję w sprawach religijnych. Równie wybitnymi postaciami byli tłumacze druków katechetycznych: Adrian Jung - znany z prowadzenia polemik z różnowiercami i Jakub Wujek - autor najbardziej znanego thumaczenia Biblii na język polski.

\subsection{Katechizm rzymski na ziemiach polskich}

Powstanie Katechizmu rzymskiego związane jest z uchwałami Soboru Trydenckiego, w którego obradach członkowie Towarzystwa Jezusowego brali czynny udział.

W literaturze przedmiotu datacja tego dzieła oraz autorstwo nie są jasno określone, należy jednak zauważyć, że autorzy przedmów zaznaczają duży wkład jezu- 
itów w powstanie katechizmu. Jan Brzezinski - autor przedmowy do wydania Katechizmu rzymskiego w 1762 r. napisał:

Koncilinm żadnej o tym wzmianki nie czyni. Świadczy Christophorus de Sanctotis augustianin eremita, iż Serpiando tegoż zakonu, dziewiaty artykut Składu Apostolskiego polecony byt. Czwarty zaś Michat de Medina Z.S. Fran. sam sobie poleconym być twierdzi Praef. ad opusc. de eod. Art. Possewin jezuita powiada, iż Piotrowi Galesmo Przykazania Boże (a pewnie część ich) do wytożenia zlecone były. A Julitszowi Spogiano ostatni księgi rozdział. W Rzymie zaś cała księga zlecona naprzód byta do rewizyi Leonardowi Marcinowi Gemueńczykowi Arcybiskupowi Lancyaneńskiemu, drugiemu Idziemu Fuscarario Bonończykowi theologowi króla Luzytańskiego na Koncilium Trydentskim, wszystkim trzem Dominikanom, z czego niektórzy przeciwni Sentencyom Dominikańskim, bardzo niekontenci byli. Powtóre tedy zlecona była Gwilelmowi Sylertowi... Ten z wieh innemi theologami, po kilkakroć najmniejsze stowa i sentencje ksiegi tej trutynowat, polerowat i rozważat: aż ja też Piusowi V do aprobaty poddat. Lecz przed wszystkimi najwięcej okoto tej księgi S. Karol Boromeusz pracowat, który jej i poczatku konsultorem i pracy wszędy koadiutorem, i konkhizyi nakoniec z aprobata oratorem byt najmocniejszym ${ }^{2}$.

Potwierdzenie udziału wyżej wymienionych osób w pracach nad przygotowaniem katechizmu odnajdujemy we francuskim wydawnictwie Biographie Générale.

Na obszarze Rzeczypospolitej ukazały się dwa wydania Katechizmu rzymskiego. Walenty Kuczborski dokonał jego tłumaczenia na język polski w 1568 r. (dwa lata po wydaniu rzymskim), które opublikował w drukarni Mikołaja Szarfenbergera. Prymas Stanisław Karnkowski zmienil nieco oryginał pod względem formy, dzieląc całość dzieła na pytania i odpowiedzi, a następnie wydrukował go u Jana Wolrada w Kaliszu. Odbiorcy otrzymali ten katechizm w 1603 r.

Jan Brzeziński, wydając Katechizm rzymski w XVIII w., nie podał nazwiska tłumacza. Stanisław Obirek SJ w swojej najnowszej książce Jezuici w Rzeczypospolitej Obojga Narodów wskazał jako thumacza jezuitę: a jego nowe thumaczenie z $1603 \mathrm{r}$. wydane staraniem prymasa Stanisława Karnkowskiego wyszło niewatpliwie spod pióra Adriana Junga ${ }^{3}$. Współpraca jezuity ze Stanisławem Karnkowskim została potwierdzona na przykładzie dwóch innych dzieł, które napisał Adrian Jung ${ }^{4}$ a wydano je jako prace prymasa: Messiasz z 1597 r. oraz Eucharistia z 1602 r.

\subsection{Katechizm Benedykta Herbesta}

Pierwszy polski katechizm, wydany w Krakowie w 1566 r. u Mateusza Siebeneichera, jest autorstwa Benedykta Herbesta ${ }^{5}$. Został napisany, jak zaznacza autor, dla rozwiązania wątpliwości w wierze, do czytania domowego w dni święte, do przygotowania się godnego do sakramentów, jak również dla kapłanów, by lepiej głosili Słowo Boże. 
Praca została ułożona w formie rozmowy kapłana $\mathrm{z}$ uczniem, którego autor $\mathrm{w}$ tekście nazywa mieszczaninem. Tacy uczestnicy herbestowskiego dialogu katechizmowego wskazują na wielką troskę autora o stan mieszczański. Mogła ona być podyktowana licznym przypadkami przechodzenia na wyznanie reformowane członków tej grupy społecznej w Rzeczypospolitej XVI w.

Przedmowa, jaką napisał Herbest, stanowi w pierwszej części traktat teologiczny. Warto zaznaczyć, iż jest to pierwszy w literaturze polskiej tekst wydany w języku ojczystym na temat głównych prawd dogmatycznych Kościoła katolickiego.

W traktacie, wychodząc ze Starego Testamentu, ukazuje Herbest figury teologiczne w Nowym Testamencie. Przedstawia istnienie wiary jako racje historyczno-teologiczne, które znalazly swoje spełnienie w Jezusie Chrystusie. Podkreśla bardzo mocno znaczącą rolę papieża, pozbawiona jego przywództwa łódź wiary chrześcijańskiej mogłaby żeglować bez konkretnego celu.

Przedmowa składa się z dwóch zasadniczych części. Pierwsza jest skierowana do Ku Wielmożnym y Szlachetnym Panom, Radzie y Rycerstwu Królestwa Polskiego. W drugiej części zatytułowanej Do Panów, Mieszczan y wszystkiego Pospólstwa chrześcijańskiego napominanie, autor wskazuje przede wszystkim na potrzebę pogłębienia tzw. pobożności żywej. Zachęca czytelników do ciaggłego dawania świadectwa swojej wiary poprzez modlitwę i uczynki chrześcijańskie.

Karol Mazurkiewicz w taki sposób tłumaczy poczynania Benedykta Herbesta:

Nauki swe pisze wprawdzie w pierwszym rzędzie dla pospólstwa, więc niższych stanów, nie znajacych taciny, jednakże i stany wyksztatcone miaty tu znaleźć odpowiednie dla siebie pouczenie. Dlatego w trakcie swych pouczeń katechizmowych Herbest często odzywa się do panów i chtopów, do mieszczan i rzemieślników, nawet do kapłanów i biskupów. Dlatego daje Herbest w swej pierwszej przedmowie dla szlachty $i$ duchownych, których wiara najbardziej była zagrożona osobne ugruntowanie wiary - argumenta fidei - aby nie wierzyli na ślepo, ale też rozumieli, dlaczego wierza i z przekonania stali niezachwianie przy sztandarze swej wiary. Zwracajac się zas do niższych stanów w drugiej przedmowie, Herbest nie wysuwa na pierwszy plan teologiczno-rozumowego przenikania wiary, lecz domaga się praktycznej pobożności, walki z chorobami duszy, powolności i postuszeństwa wobec przewodników duchownych. ${ }^{6}$

Na początku katechizmu Herbest umieścił rozdzial $O$ ksiażkach polskich, w którym starał się wytlumaczyć czytelnikowi, że pisanie dzieł o tematyce religijnej jest bardzo trudne. Wskazal jako przykład trudności lęk przed napisaniem czegoś, co byłoby niezgodne z myślą Kościoła. Lud Boży powinien zasadniczo umacniać swoją wiarę poprzez słuchanie Słowa Bożego z ust jego kapłanów, a nie z książek. Podaje główny powód podjęcia się tego dziela: Gdyby nie byto tego potrzeba dla ludu kacerskiego, nigdyby tego nie uczynit. Widać tutaj bardzo wyrażnie, że katechizm jest bardziej wynikiem rywalizacji pomiędzy wyznaniami niż wewnętrzną potrzebą autora. 
Twórca zaznacza bowiem, że samo czytanie katechizmu powinno odbywać się z dużą pobożnością i namaszczeniem.

Należy również zauważyć, iż Benedykt Herbest był profesorem Akademii Lubrańskiego. Cel, który przyświecat Herbestowi przy pisaniu „Nauki”, był wyraźnie pastoralny. Miat to być rodzaj podręcznika wiary, i to zarówno dla osób wykształconych, jak i prostych. W pierwszym rzędzie miat shuzyć duchownym, absolwentom Akademii?. Chciał więc autor dać młodym duchownym odpowiednie narzędzie do pracy duszpasterskiej, które ułatwiłoby im kształtowanie właściwych postaw religijnych i odpowiadało czasom, w jakich przyjdzie im prowadzić działalność ewangelizacyjną. Pamiętać należy, iż właściwą formą dominująca w Kościele katolickim bylo gloszenie słów Pisma świętego z ambony, a nie dostarczanie literatury do czytania wierzącym. Pierwszym krokiem ku takiej formie szerzenia w sposób powszechny wiary były prace katechetyczne Marcina Lutra. Wymuszaly one odpowiedź ze strony Kościoła katolickiego i w tym duchu napisal pierwszy polski katechizm Benedykt Herbest.

\section{2.a Treść katechizmu Benedykta Herbesta}

Cały katechizm podzielił Benedykt Herbest na trzy części, co odpowiada trzem cnotom głównym. Pierwszy rozdzial o wierze odnosi się do analizy wyznania wiary, które zostało podzielone na dwanaście artykułów. Warto je wymienić wszystkie w kolejności występowania, ponieważ w ten sam sposób dzielony był Sklad Apostolski we wszystkich katechizmach.

1. Wierzę w Boga Ojca Wszechmogącego stworzyciela nieba i ziemi;

2. I w Jezusa Chrystusa, Syna jego jedynego Pana naszego;

3. Który się począł z Ducha świętego, narodził się z Panny dziewicy;

4. Cierpiał pod Ponskim Piłatem, ukrzyżowan, umarł i pogrzebion;

5. Stąpil do Piekieł, trzeci dzień Zmartwychwstal;

6. Wstąpił na niebiosa, siedzi na prawicy Boga Ojca Wszechmogącego;

7. Stądże przyjdzie sądzić żywe i umarłe;

8. Wierzę w Ducha świętego;

9. Święty Kościół Powszechny, świętych obcowanie;

10. Grzechów odpuszczenie;

11. Ciała zmartwychwstanie;

12. I żywot wieczny.

Amen $^{8}$.

Zasadnicza część wykładu poszczególnych zdań z credo jest poświęcona obrzędom w Kościele katolickim. Jest to, jak przyznaje K. Mazurkiewicz, pierwszy w języku polskim traktat liturgiczny. Herbest tłumaczy polskie święta, uzasadniając ich istnienie w sensie historycznym oraz wyjaśnia ich symbolikę. Opiera się 
w swoich wywodach na Piśmie Świętym, Ojcach Kościoła (Bazylim, Ambrożym, Augustynie, Hieronimie) i soborach (nicejskim, bazyliańskim, trydenckim).

Druga część katechizmu - O nadziei i pacierzu - rozpoczyna się wykładem na temat modlitwy. Akcentuje, że całe życie człowieka powinno być jak jedna wielka modlitwa. Elementem zasadniczym w modlitwie jest pokora wewnętrzna, a zewnętrznie powinna objawiać się poprzez postawę klęczenia. Rozmówca obawia się reakcji społeczności. Ale dziś hypokrytami zowiq takich, na co kapłan mu odpowiada: A kto, Pikarci, czyli lıteranie ${ }^{9}$. Herbest wyróżnia trzy rodzaje modlitwy: dziękczynną, błagalną i pochwalną. Analizuje dokładnie dwie: Modlitwę Pańską i Pozdrowienie Anielskie.

Trzecia część katechizmu nosi tytul: O mitości i przykazanilı Bożem, autor omawia tutaj pojęcie grzechu, dobrych uczynków, a przede wszystkim dziesięć przykazan. Ostatnie dwa prawa Mojżeszowe przedstawił jako jedno: Nie pożqdaj żony Brata twego ani żadnej rzeczy iego ${ }^{10}$. W tekście katechizmu wyjaśnia, iż widzi powtórzenie prawd zawartych w przykazaniu dziewiątym i dziesiątym z nakazami ujętymi w szóstym i siódmym przykazaniu. Bóg, jak twierdzi autor, lubi liczby 10 i 12 (podzial Składu Apostolskiego), dlatego ustalił tyle prawd dla człowieka" ${ }^{\prime \prime}$. Herbest w końcowej części katechizmu umieścił trzy dodatki mówiące o wadze dziesięciu przykazań, warunkach dobrego przygotowania się do sakramentu pokuty i najważniejszym przykazaniu miłości. Całość dzieła zamyka nauka eschatologiczna o życiu i śmierci.

W katechizmie Herbesta brakuje dokładnego omówienia pojęcia łaski Bożej i wszystkich sakramentów. To ostatnie zagadnienie przedstawione zostało tylko pod kątem obrzędów. Brak również przedstawienia przykazań kościelnych, które w tamtych czasach nie posiadały jednolitego brzmienia w języku polskim.

Oryginalność pracy Herbesta, jak zauważył K. Mazurkiewicz, polega na tym, że pytania stawia z reguty nie nauczyciel, lecz uczeń, $w$ tym przypadku mieszczanin, podczas gdy w dzisiejszych katechizmach pytajacq osoba jest ze zrozumiatych względów nauczyciel' ${ }^{12}$.

Benedykt Herbest napisał dzieło, które w języku polskim nie miało sobie podobnych wzorów, co stanowi niewątpliwie zaletę katechizmu. Nie mógł oprzeć się na Katechizmie trydenckim, albowiem ten ukazal się poźniej i był przeznaczony dla nauczycieli oraz duszpasterzy. Herbest nie znał języka niemieckiego, nie mógl więc czytac katechizmów różnowierczych w oryginale, ale mógł znać ich tłumaczenia, które ukazaly się w Rzeczypospolitej na początku XVI w. Największych wpływów na dzieto Benedykta Herbesta należy doszukiwać się w Confessio fidei Stanisława Hozjusza. Porównując te dwie prace, możemy dostrzec, iż wiedza religijna jest uporządkowana podobnie jak w dziele warmińskiego kardynała - występuje podział na trzy zasadnicze części: wiara, nadzieja, miłość. Różnica pomiędzy tymi dziełami polega na stylu wypowiedzi i języku. Confessio napisane było dla teologów i po łacinie, stylem typo- 
wo naukowym, dzieło Herbesta zaś - przystępnie i zrozumiale dla przeciętnego czytelnika i dla studentów Akademii Lubrańskiego.

\section{TEUMACZENIA KATECHIZMÓW KATOLICKICH - JEZUICI}

Compendium doctrinae christianae Roberta Bellarmina ukazało się w 1606 r., na obszarze Rzeczypospolitej zaś w 1608 r. pod tytułem Sumariusz nauki chrześciańskiey. Niestety nie zachowało się pierwsze wydanie dzieła w języku narodowym. W naszych badaniach poshużyliśmy się drugim tłumaczeniem tego autora, którego dokonał Marcin Szyszkowski w 1611 r., a które zostało przygotowane w drukarni Andrzeja Piotrkowczyka. Katechizm Bellarmina wznawiany był w Polsce 32 razy, doczekał się również tłumaczenia na język ruski w 1633 r. Wszystko dzięki wsparciu, jakie dzieło otrzymało od papieża Klemensa VIII, ktory listem Pastoralis Romani zalecil używanie go przez wiernych Kościoła katolickiego ${ }^{13}$.

Dzieło zostało napisane $w$ formie rozmowy pomiędzy mistrzem a disputatem. To określenie łacińskie rozmówcy wskazuje na podkreślenie znaczenia osoby, która stara się poznać prawdy wiary. W katechizmach, jakie omawialiśmy, nazywano uczestników dialogu mistrzem i uczniem, tłumaczenie zaś słówka disputator jako myśliciel, badacz naukowy, podnosi rangę rozmówców. Nie jest to dialog pomiędzy jakimś uczniem szukającym wiary, ale myślicielem, czyli kimś zdecydowanie lepiej przygotowanym do wspólnego zgłębiania dogmatów.

Kolejnym katechizmem, jaki został przetłumaczony na język polski, jest praca Piotra Kanizjusza. Do napisania dzieła namawiał jezuitę cesarz Ferdynand. H. Tüchle twierdzi:

Ponieważ katechizmy Lutra rozpowszechniaby się także wśród austryjackiego ludu, Ferdynand życzyt sobie, by opracowano katechizm katolicki. Tak więc Kanizjusz opublikowat swój pierwszy katechizm, zawierajacy zbiór odpowiedzi na 213 pytań, z wieloma cytatami z Biblii i z dzieł Ojców Kościoła. Katechizm nie był utrzymany w tonie polemicznym - nie wspomniano w nim wcale o Lutrze - lecz w tonie pozytywnym; zwalczat jedynie podstawowe zto ostatnich dziesięcioleci: teologiczna niejasność i rażaca ignorancje $w$ sprawach religijnych. Po pierwszej wersji katechizmu, przeznaczonej dla studentów, ukazaty się dwie inne w języku tacińskim, a później także wersja niemiecka, przeznaczona dla prostego ludu i dla dzieci. Maty katechizm, który ukazat się w 1560 r. w przekładzie niemieckim, ozdobiony drzeworytami i zaopatrzony w kalendarz, stat się wręcz popularnym podręcznikiem dla niemieckich katolików na blisko 200 lat. Katechizm ten jeszcze w XVI w. doczekat się 200 wydań, a ogółem miat ich 550 oraz liczne przektady ${ }^{14}$.

W Rzeczypospolitej ukazał się w 1570 r. w tłumaczeniu Jakuba Wujka w drukarni Mateusza Siebeneichera. J. Terlaga, badacz dzieł jezuity, stwierdza, iż katechizm ten nie zachował się do naszych czasów ${ }^{15}$. 
Drugim katechizmem, jaki przetłumaczył Jakub Wujek, była praca hiszpańskiego jezuity Jakuba Ledesmy (1520-1575), opublikowana w 1572 r. Niestety żaden $\mathrm{z}$ tych katechizmów się nie zachował. Praca Ledesmy została przetłumaczona na język żmudzki przez litewskiego jezuitę Mikołaja Dauksztę (Katechismas arba mokslas kiekwienam krikszczionnii priwalvs. Paraszitas per D. Jakuba Ledesma Theologa Societatis Jezu) w 1595 r. oraz wydana ponownie w 1605 r. Badacz dziewiętnastowieczny Jan Bystroń w przedmowie do wydania katechizmu Ledesmy stwierdza, że prawdopodobnie istniało jego tłumaczenie polskie ${ }^{16}$.

Potwierdza to tezę, iż praca hiszpańskiego jezuity w Rzeczypospolitej była znana, ale nie zachowal się żaden egzemplarz. Katechizm, który został przetłumaczony na język polski $\mathrm{i}$ jest dostępny w Polsce, to dzieło Bellarmina; będzie on stanowił podstawę naszej analizy.

\subsection{Przyczyny wydania i adresaci katechizmu}

Katechizm Roberta Bellarmina został przygotowany do druku na zlecenie biskupa Marcina Szyszkowskiego, który w przedmowie uzasadnił przyczyny wydania tego dzieła:

Najaśniejszy Królewicu: która ta ksiqżka, iż pobożnego życia nauki w sobie zawiera, zdało mi sie ja do używania i nauki jasności W. a zaraz dla Diocezyej moiej Ptockiej, do klórej mnie Pan Bóg powotał na tacińska i Polski przełożywszy, jaś. W. przypisać $i$ oddać. ${ }^{17}$

W dalszej części przedmowy Marcin Szyszkowski podkreśla, iż pragnie, aby katechizm przyczynił się do ugruntowania wiary Władysława IV. Warto zwrócić uwagę, że jest to praca przeznaczona bezpośrednio dla diecezji plockiej. Omawiane wyżej katechizmy nie posiadały określonego przeznaczenia terytorialnego.

Katechizm Roberta Bellarmina pod względem objętości jest najmniejszym dzielem katechetycznym. Uwzględniając czas powstania (przełom XVI i początek XVII w.), dostrzegamy przemiany tego rodzaju piśmiennictwa w Kościele katolickim. Pierwsze katechizmy, a przede wszystkim Katechizm rzymski, były stosunkowo obszerne. Wynikało to z potrzeby udzielenia odpowiedzi chrześcijanom na pytania, jakie pojawiały się w czasie reform. Schyłek XVI w. nie wymagał już tak obfitych prac; autorzy zaczynaja publikować dzieła zdecydowanie mniejsze i bardziej przystępne przeciętnemu czytelnikowi. Nie ma już potrzeby douczania duchowieństwa, tę funkcję przejmują seminaria. Katechizm staje się źródłem najważniejszych wiadomości religijnych dla prostego ludu.

\subsection{Treść katechiznu}

Katechizm rozpoczyna omówienie roli, jaką odgrywa w Kościele rzymskim credo, Trójca Przenajświętsza oraz znak krzyża. Autor przedstawił Skład Apostolski 
w formie podziału na dwanaście członów wiary, które najpierw wymienił, a następnie objaśnił. Prezentując dziewiąty artykuł wiary, podal definicję Kościoła:

Ja tymże sposobem wierzę, iż jeden jest Kościót, który jest zebraniem wszystkich wiernych chrześcijan, którzy się ochrzcieli $i$ wierza a wyznawajq wiarę Chrystusa Zbawiciela i znaja jego namiestnika na ziemi najwyższego, Biskupa Rzymskiego. ${ }^{18}$

Jest to bardzo wyraźne zwrócenie uwagi autora na jego związek z Kościołem katolickim, podkreślenie roli papieża niewątpliwie wskazywało jednoznacznie na pochodzenie katechizmu. Warto zaznaczyć, iż cała praca Bellarmina pozbawiona jest jakichkolwiek uwag pod adresem różnowierców. Pracę tę charakteryzuje pozytywne prezentowanie prawd wiary.

W następnej części katechizmu autor przedstawił modlitwy Ojcze nasz i Zdrowaś Maryjo. Umieścił w całości obydwie te modlitwy, co wyróżnia pracę spośród innych, w których omawiano je w podziale na poszczególne akapity. Zdrowaś $\mathrm{Ma}$ ryjo to modlitwa, do której odmawiania zachęca Bellarmin po wypowiedzeniu pacierza. Abym za przyczyna tej najświętszej Panny fatwiej mógt otrzymać to, czego proszę od Boga. ${ }^{19}$

W trzecim rozdziale prezentowane są przykazania Boże. Autor jest tutaj bardzo oszczędny w formułowaniu wniosków, praktycznie ograniczył się do przedstawienia treści przykazania i w jednym zdaniu udzielił komentarza. Ostatnie dwa przykazania zostały przedstawione w jednym komentarzu: Rozkazuje Bóg w ostatnich obu przykazaniach, żeby żaden nie pożadat ani żony, ani cudzej rzeczy ${ }^{20}$. Warto podkreślić, że autor dziewiąte przykazanie ograniczył w porównaniu z wcześniejszymi katechizmami do niepożądania żony, pominął określenia wołu czy osła, jakie były w pracach wcześniejszych.

W tym samym rozdziale Robert Bellarmin umieścił przykazania kościelne; ten element pojawia się w katechizmie po raz pierwszy, dlatego warto przytoczyć odpowiedni fragment:

1. Shuchaj Mszy św.,

2. Posty zachowywać,

3. Spowiadać się i komunię przyjmować,

4. W czasach zakazanych zabaw hucznych nie urzqdzać,

5. Dziesięciny ptacić. ${ }^{21}$

Część czwarta katechizmu poświęcona jest omówieniu sakramentów świętych. Autor wymienił je w takiej kolejności, jaka dzisiaj występuje w dzielach katolickich. Nazwał tylko sakrament eucharystii sakramentem najświętszego stoht ${ }^{22}$. Nie wspomniał autor o udzielaniu komunii św. pod dwiema postaciami. W kolejnej części przedstawił cnoty boskie i główne nazwane gruntownymi.

Ostatnia część katechizmu poświęcona jest grzechowi. Bellarmin podzielił grzechy na pierworodny i uczynkowy, w tym ostatnim rozróżnia śmiertelne i powsze- 
$d n i e^{23}$. Autor w sposób graficzny przedstawił grzechy główne oraz ich przeciwieństwa:

$$
\begin{aligned}
& \text { Pycha - pokora } \\
& \text { takomstwo - szczodrobliwość } \\
& \text { nieczystość - czystość } \\
& \text { gniew - cierpliwość } \\
& \text { obżarstwo - wstrzemięźliwość } \\
& \text { zazdrość - mitośc braterska } \\
& \text { lenistwo - pilność }{ }^{24}
\end{aligned}
$$

Warto zwrócić uwagę, iż po raz drugi w katechizmie autor posłużył się forma graficzną do prezentowania prawd wiary; pierwszy uczynił to Marcin Białobrzeski ukazując różnice dogmatyczne w pojmowaniu Trójcy Świętej pomiędzy katolikami a różnowiercami.

Ostatnim elementem katechizmu jest przedstawienie modlitwy różańcowej, która w katechizmach w XVI i na początku XVII w. nie była omawiana. Zadaniem tej modlitwy, według autora, jest podtrzymywanie wiary i nabożeństwa do Boga i Matki Jego.

Cała pracę charakteryzuje brak odniesien do różnowierców. Bellarmin nie podjął polemiki $z$ ruchem reformatorskim. Nie umieścił również, jak to miało miejsce we wcześniejszych katechizmach, cytatów z Pisma Świętego. Praca ta niewątpliwie jest najbardziej zbliżona do katechizmów, jakimi posługujemy się dzisiaj. Niezwykle oszczędna pod względem komentarza, zawiera najważniejsze zasady Kościoła, które powinien znać każdy katolik.

Zmiana, jaką obserwujemy w pisaniu katechizmów, od pierwszych prac Marcina Białobrzeskiego poprzez Katechizm rzymski, to ciagge upraszczanie tego rodzaju dzieł. Na początku XVII w. funkcjonowały przekłady Biblii na języki narodowe, dlatego zanikła potrzeba wzmacniania treści katechizmowych cytatami. Zanikała walka o wyznawców, co łagodziło prace tego typu. Katechizm stawał się kompendium wiedzy religijnej, a nie narzędziem propagandy czy walki pomiędzy wspólnotami chrześcijańskimi.

\section{FUNKCJE I ODBIORCY KATECHIZMÓW}

Katechizm rzymski skierowany był bezpośrednio do stanu duchownego, dlatego zadania, jakie miał spełniać, odnoszą się wprost do pracy duszpasterskiej:

Ale iż to święte zebranie tylko to przedsięwzieto, aby plebanom kaptanom i opiekalnikom dusznym te nauki ku poznaniu podato, która właśnie urzędowi pasterskiemu należy, a którq by ludzie snadniej pojać mogli: tedy tylko to chciało zamknqć w tych księgach co by mogto pobożność pasterska zachować, zwtaszcza jeśliby w trudniejszych rzeczach Boskich rozbieraniu nie byli ćwiczeni. ${ }^{25}$ 
Ojcowie Kościoła wykazali wielką troskę o należyte wyposażenie duchownych w zbiór podstawowych prawd wiary, które mogłyby pomóc w pracy na niwie Pana. W pierwszym polskim wydaniu tłumacz, uzasadniając pracę, zwiększył liczbę odbiorców:

A chociaż osobliwie ten katechizm pisano dla plebanów, którzy ludzie inne uczyć maja wszakże my go ku pożytku wszystkim wobec wydajemy i łaskawych czytelników pilnie prosimy, aby ta praca nasza gardzić nie chcieli. ${ }^{26}$

Tłumaczenia katechizmów na języki narodowe niewątpliwie przyczyniły się do rozszerzenia grona odbiorców. Łacina była znana najpowszechniej w środowisku duchownych oraz ludzi wykształconych. Wiek XVI wraz z duchem odrodzenia wniósł potrzebę pisania i czytania w językach ojczystych.

Karol Boromeusz, który wniósł największy wkład do wydania Katechizmu rzymskiego, na synodzie mediolańskim w 1565 r., czyli jeszcze przed ukazaniem się drukiem tego dzieła, zalecał:

Klerycy, gdy do czternastego roku życia przyjda, ażeby prawo Pańskie, kióre szczególnie zobowiazani zachować sq, dniem i noca rozmyślać mogli, ksiąg świętych, jeżeli nie obfitość, przynajmniej wybór niech majq, nieuchronnie zaś stary i nowy Testament, tudzież katechizm w Rzymie majacy być wydany, jak sie tylko pokaże. ${ }^{27}$

Jan Brzeziński w przedmowie do Katechizmu rzymskiego wydanego w 1762 r. wychwalał zalety i jednocześnie poszerzyl krąg odbiorców tego dziela:

Jest to bowiem słonce prawdy, uspokojenie duszy, reguty niebieskiego życia, oryginatem nauki, madrościq najpożadniejsza, konwikcja najjaśniejsza. Jest zaś wszystko wszystkim: kapłani majq naukę niepochybnq, która sami pilnować powinni. Świeccy maja zabawę najpilniejsza, która petniqc, żyć na wieki będq. Madrzy ludzie maja zbiór najrozliczniejszych madrości. Nieluzem maja Najwyższq szkołę Ducha Najś. Misjonarze, kaznodzieje maja gotowe kazania, które z ambon czytać moga. Gospodarze maja dla domowej czeladki instrukcje, do kaptaństwa przystepujacy, i kaptani niebiegli w theologii maja zebrania wszelkiej theologii, szkolnej, moralnej, ascetycznej, skrypuualnej, kontrowersystycznej, czyli polemiki. Białogłowy na koniec, dysput częstokroć i nauki chciwe, więcej pożytecznych $w$ żadnej księdze nie znajdq. ${ }^{28}$

Idea powiększenia kręgu odbiorców, jak wynika z powyższego cytatu, przyświecała tłumaczeniu Karnkowskiego, który zmienił formę Katechizmu rzymskiego poprzez podzielenie na pytania i odpowiedzi.

Jednak w XVI w. głównym odbiorcą miał być przedstawiciel stanu duchownego. Zalecenia synodów prowincjonalnych w Europie i Polsce wskazują na kolejne zadania, jakie miał spełniać katechizm:

Po nim Synod Benewentański w r. 1567 przykazuje wszystkim plebanom i kaznodziejom, aby ten katechizm zawsze w ręku i przed oczami mieli, aby zdrowej nauki w czym nie przestapili. R. 1568, który go Katechizmem Rzymskim nazywa i dziwnie 
wynosi, przykazuje seminariom swoim, aby z rak ich nigdy nie wychodzili. Zaś S. Karol na synodzie Mediolaniskim 1569 przykazat plebanom, aby się schodzac (na kongregacjach) lekcje jakq z niego między soba repetowali... Osobliwsza już rzecz S. Karol na Mediolanskim 1576 roku przykazat, aby między księgami, które plebani przy biskupich wizytacjach prezentować powinni, $i$ ten tez katechizm byt prezentowany. ${ }^{29}$

W Rzeczypospolitej zalecenia dotyczące katechizmu były następujące:

Aczkolwiek lepsza częś́ synodów starych, przed czasów uszczerbkiem, do naszej pamięci nie doszta, i w tym jednak, co pilny Antiquitatis Scrutator J.O. Author nasz, będqc jeszcze biskupem kujawskim, zgromadzit i zanotowat, semina gorliwości przodków naszych i powszechnej katechizmu tego akceptacji wydaje się: gdy lib. 5. C.26 Cons. Synod sub. Joan. Wężyk edit. czytam po szkotach publicznie czytać rozkazano. $Z$ powiększych synod Piotrkowski za kardynata-prymasa Maciejowskiego 1607. tit. de Doctr. Fid. Cathol. propag. Kazania część jedna z ewangelii, drugq z Katechizmu Rzymskiego na każde święto plebanom miewać przykazat. Toż samo synod Piotrkowski pod prymasem Wężykiem 1629 postanowit. ${ }^{30}$

Bielski w przedmowie wskazał pierwszy synod w Polsce (Piotrków 1589), który zalecil Katechizm rzymski. Temu zgromadzeniu przewodził Stanisław Karnkowski ${ }^{31}$.

Warto zwrócić uwagę, iż w większości autorzy katechizmów polskich to nieprofesorowie: Marcin Kromer, Hieronim Powodowski czy Marcin Białobrzeski byli przedstawicielami duchowienstwa, którzy nie prowadzili dzialalności dydaktycznej ze studentami. Byli oczytanymi w teologii humanistami, rozumiejąc potrzebę czasu reform, podjęli się napisania prac katechetycznych. Nauka o Bogu zawarta w ich drukach określana jest jako teologia pozytywno-kontrowersyjna. Nacechowana jest odniesieniami do Pisma świętego, tradycji Kościola i Ojców Kościoła ${ }^{32}$. Jedyny wyjątek wśród autorów katechizmów stanowi Benedykt Herbest, profesor w Akademii Lubrańskiego. Jego praca przede wszystkim była adresowana do słuchaczy akademickich i zawierala bezpośrednie nauki potrzebne przy studiowaniu teologii. Wiele miejsca poświęcił autor na wyłożenie zasad posługiwania się kalendarzem liturgicznym i księgami kościelnymi.

Spośród wszystkich wymienionych zadań najważniejsze, jak się wydaje, polegato na uporządkowaniu wiary, daniu narzędzia pomocnego w pracy duszpasterskiej klerowi i rywalizacji z katechizmami różnowierczymi. Ten ostatni element bardzo ladnie ukazał Brzezinski, przedstawiając przygotowania do ponownego wydania katechizmu w XVIII w.:

$Z$ wielkim bowiem aplauzem przy poczqtkach przyjęia, na koniec tak zarzucona została, że gdy mi się jej egzemplarz z zagranicznego państwa z heretyckiej biblioteki ( $w$ klórej go osobliwsze konferowano estymacyja i na godnych ledwo ludzi prośbe $z$ trudnościq ustapiono) do druku zostat, w którym kilku wydartych kart nie stawato; 
przejrzawszy wszystkie wileńskie dośc liczne i staremi księgozbiorami zaszczycone biblioteki i dalsze, gdziem tylko przez czas mógt uczyniwszy starania po różnych stronach, nigdzie przecie o drugim egzemplarzu dowiedzieć się nie mógt, czy dla dawności czasu wszystko gubiacej, czy też (co podobniej) dla heretyckich podstępków $i$ wykupienia. $^{33}$

W katechizmach katolickich dwa ostatnie przykazania uwydatniaja stosunek Kościoła do kobiety. Nie wymieniano na pierwszym miejscu w przykazaniu dziewiątym zakazu pożądania żony bliźniego, ale akcentowano zakaz pożądania dóbr materialnych. Jak twierdzi Andrzej Karpiński:

Podstawowa role, jaka wyznaczono kobiecie, była rola żony, matki. Propagowat ja Kościót katolicki oraz promatrymonialnie nastawione miejskie ustawodawstwo różnych szczebli. Kaznodzieje duchowni lansowali dwa modele kobiety zamężnej: niewiasty silnej, prowadzqcej rodzinę, wychowujacej dzieci i shużacej mężczyźnie oraz istoty cichej, spędzajacej większość czasu na kontemplacji i modlitwie, pokornie wypetniajacej swe obowiazki i gardzacej światem. ${ }^{34}$

Analizując cały katechizm Benedykta Herbesta, łatwo zauważyć, iż autor podkreśla te treści wiary katolickiej, z którymi polemizowali różnowiercy, tak więc katechizm ma charakter apologetyczny. Elementy, które pominął Herbest świadomie, znajdują swoje dopełnienie w innych jego dziełach. Zaznacza to sam na marginesach katechizmu. Przyglądając się dokładnie treści, możemy spostrzec, że katechizm nie stanowi pewnej całości, jest raczej wynikiem walki z dziełami różnowierców, a $z$ drugiej strony podsumowaniem pracy dydaktycznej i kaznodziejskiej samego autora. Widać to wyraźnie w porównaniu stylu i argumentacji w pierwszym rozdziale, a wręcz kaznodziejstwem w dwóch pozostałych częściach.

Katechizmy katolickie, poza treściami teologicznymi, podejmowały zadania związane $\mathrm{z}$ funkcjonowaniem duszpasterzy, udzielając im pomocy w wypełnianiu obowiązków.

Jezuici, przywiązując dużą wagę do reewangelizacji, w XVI w. uznali, że kompendium wiedzy teologicznej, jakim był i jest katechizm, będzie doskonałym narzędziem do powrotu do źródeł chrześcijaństwa. Apologetyczne nastawienie wielu kaznodziejów jezuickich również wzmacniało potrzebę pracy nad katechizmami układanymi w formie pytań i odpowiedzi. 


\section{Przypisy}

' Zob. M. Bednarz, Jezuici w religijności polskiej (1564-1964), „Nasza Przeszłość” 20, 1964 , s. 162-165.

2 J. Brzezinski, Przedmowa, w: Katechizm Rzzmski z dekretu s. Koncilium Trydentskiego za rozkazem s. Pilısa V papieza po lacinie wydany, wyd. idem, Wilno 1762, s. 6.

${ }^{3}$ S. Obirek, Jezuici w Rzeczvpospolitej Obojga Narodów w latach 1564-1668, Kraków 1996, s. 59.

${ }^{4}$ Zob. B. Natoński, Jung Adrian, w: Polski Stownik Biograficzny (dalej: PSB), t. XI, s. 324-326. Adrian Jung (ok. 1550-1607) urodzil się w Plonsku na Mazowszu w rodzinie pochodzenia szkockiego. Studiowat na Akademii Krakowskiej 1569/70. W lutym 1570 r. wstapil do Towarzystwa Jezusowego, a w 1580 r. otrzymał święcenia kapłańskie. Początkowo wykladał w Kolegium Poznańskim dialektykę i retorykę. Doświadczenia dydaktyczne sprawily, iż z biegiem czasu postanowił zając się polemiką z różnowiercami. Jego działalność przyniosla mu uznanie i nosi Jung miano jednego z najpoważniejszych polemistów kontrreformacji w Polsce. Najbardziej znanym jego dziełem jest Rozwiazanie pięcidziesial y' dwu quaestiy' z 1593 r., które było odpowiedzią na publikację Grzegorza z Żarnowca Trakracik albo 52 quaestiy o kościele bożym wydana w 1590 r. Na początku XVII w. Jung przebywał w Poznaniu i Kaliszu, gdzie wspólpracowal z prymasem Stanisławem Karnkowskim.

${ }^{5}$ Zob. I. Zarębski, Herbest Benedykt, PSB, t. 9, s. 434-436 i E. Wyczawski, Herbest Benedykt, w: Slownik Polskich Teologów Katolickich, t. 2, s. 36-39. Benedykt Herbest urodzil się ok. 1531 r. w Nowym Mieście w Ziemi Przemyskiej w wywodzącej się z Niemiec drobnomieszczańskiej rodzinie jako syn Stanislawa i Zofii. Studiowal w Akademii Krakowskiej na wydziale artium, gdzie uzyskal tytuł bakalureata w 1550 r. Poczatkowo pracowal jako nauczyciel w szkolach parafialnych, póżniej pełnił funkcje rektorskie w miejskiej szkole we Lwowie (1555-1558). W 1559 r. uzyskal tytul magistra sztuk wyzwolonych. Wykładał w Akademii Krakowskiej. W 1563 r. przeniósi się do Poznania, aby wykładać w Akademii Lubrańskiego, uzyskał w tym samym roku kanonie w kapitule poznańskiej, tak więc miał już święcenia kaplańskie. W 1571 r. wstąpil w Rzymie do Towarzystwa Jezusowego. Po powrocie do Polski uczyl w kolegiach jezuickich w Pultusku, Malborku i Jarosławiu. W 1584 r. zostal superriorem rezydencji we Lwowie. W 1594 r. mieszkal w kolegium w Jaroslawiu i tam zmarl 4.03 .1598 r.

' K. Mazurkiewicz ks., Benedykt Herbest. Pedagog - organizator szkoty polskiej XVI w. Kaznodzieja - misjonarz doby reformacji, Poznań 1925, s. 200.

${ }^{7}$ A. Weiss, Studium teologii w Akademii Lubrańskiego (1519-1572), w: Dzieje Teologii katolickiej w Polsce, t. 2, cz. 2, Lublin 1975, s. 37.

${ }^{8}$ B. Herbest, Nauka prawego chrześcijanina, Kraków 1566, s. nlb.

${ }^{9}$ ibidem, s. nlb.

10 ibidem, s. nlb.

11 ibidem, s. nlb.

12 ibidem, s. 222.

${ }^{13}$ Zob. S. Obirek, op. cit., s. 59.

${ }^{14}$ H. Tüchle, Historia Kościola, t. 3, Warszawa 1986, s. 139.

15 Zob. J. Terlaga, Dziatalność ks. Jakuba Wijka T.J. jako rektora kolegium Poznañskiego, Kraków 1936, s. 17.

${ }^{16}$ Zob. J. Bystron, Przedmowa, w: Katechizm Ledesmy w przekladzie wschodnio-litewskim, Kraków 1890, s. 2.

${ }^{17}$ M. Szyszkowski, Przedmowa, w: Summariusz nauki chrześciańskiey przez Cardynała Belarmina Kraków 1611, s. nlb. 
${ }^{18}$ R. Bellarmin, Summariusz nauki chrześciariskiey przez Cardynała Belarmina, Kraków 1611, s. 11.

${ }^{19}$ Ibidem, s. 20.

${ }^{20}$ Ibidem, s. 27.

${ }^{21}$ Ibidem, s. 29.

22 Ibidem, s. 30.

${ }^{23}$ Ibidem, s. 39.

${ }^{24}$ Ibidem, s. 41.

${ }^{25}$ W. Kuczborski, Przedmowa, w: Katechizm albo nauka wiary i pobożności chrześcijańskiej, Kraków 1568 , s. 4.

${ }^{26}$ Ibidem, s. 5.

${ }^{27}$ Zob. T. Bielski, Przedmowa, w: Katechizm wedtug uchwat S. Koncilium Trydenckiego, Kraków 1789 , s. 17.

${ }^{28}$ J. Brzeziński, Przedmowa, w: Katechizm Rzymski z dekretu s. Koncilium Trydentskiego, wyd. idem, Wilno 1762 , s. 1.

${ }^{29}$ lbidem, s. 7.

${ }^{30}$ Ibidem, s. 8.

${ }^{31}$ Zob. T. Bielski, Przedmowa, op. cit., s. 12.

32 Zob. M. Rechowicz, Teologia pozytywno-kontrowersyjna: Szkota Polska w XVI w, w: Dzieje Teologii katolickiej w Polsce, t. 2, cz. 1, Lublin 1975, s. 33-38.

${ }^{33}$ J. Brzezinski, Przedmowa, op. cit., s. 10.

${ }^{34}$ A. Karpiński, Kobiety w mieście polskim $w$ drugiej polowie XVI $i$ w XVII w., Warszawa 1995, s. 146. 